\title{
The Impact of HR Practices on Employees' Performance: An Imperative Role of Islamic Work Ethics
}

\author{
Abdul Qayyum ${ }^{1 *}$, Nazish Zahid ${ }^{2}$, Raja Ahmed Jamil ${ }^{3}$ \\ ${ }^{1}$ Associate Professor, FMS, Riphah International University, Islamabad, Pakistan \\ ${ }^{2}$ MS Scholar, FMS, Riphah International University, Islamabad, Pakistan \\ ${ }^{3}$ PhD Scholar, FMS, Riphah International University, Islamabad, Pakistan
}

\section{Keywords \\ Performance \\ Appraisal \\ Training \\ Empowerment \\ Islamic Work \\ Ethics (IWE) \\ Employees' \\ Performance}

Received: 8-Feb-19

Accepted: 30-Apr-19

\begin{abstract}
The purpose of this study is to investigate the impact of Human Resource (HR) practices on employees' performance with moderating role of IWE. Self-administered questionnaires were distributed and data of 307 employees were collected from telecom sector of Pakistan. Findings reveal that performance appraisal and employee's empowerment positively predict employees' performance, while the relationship with regard to training could not be established as was expected. IWE moderate the relationship between HR practices (performance appraisal and empowerment) and employees' performance. This study is useful since it provides insights into how IWE significantly improve the performance of employees within an organization when coupled with key HR practices.
\end{abstract}

KAUJIE Classification: M84, T6

JEL Classification: L25, M1

(C) 2019 JIBM. All rights reserved.

\section{INTRODUCTION}

HR practices (performance appraisal, training and empowerment) have gained focus of research in the past decade or so mainly because of their significance in rewarding managerial activities in contemporary organizations. They are important in enhancing employee's performance, which is essential for the achievement of organizational goals in today's extremely competitive environment. The optimum efficiency and effectiveness of a firm depends less on its economic resources or the newest technology than what it depends upon the extent to which it keeps its employees efficient, motivated and dedicated. In a developing economy like Pakistan, scientific HR practices have been increasingly adopted by organizations, but the process of adaptation has been slow. There can be many factors for this slow pace, but one factor can be the lack of focus on due importance to IWE. The

\footnotetext{
*Corresponding author: Abdul Qayyum

†Email: abdul.qayyum@riphah.edu.pk
} 
inspirations of Islam in relation to HR practices are an area of interest where a lot can be done in particular context of Pakistani organizations (Zahrah \& Bidayatul, 2009). More recently, Rawwas, Javed and Iqbal (2018) investigated the IWEs' moderating role between perception of organizational politics and HR related outcomes.

In Islamic society, an organization should sustain and evaluate employees' performance and organizational performance under the guidance of Islamic teachings. As Muslims, they should understand that their main intent to work is to worship Allah ('ibādah) and achieve His blessing. With that kind of perception, the whole activity at the work place is considered as 'ibādah. Through this consciousness, the individuals will put a great effort to do the best possible in their assigned responsibilities. This is because they trust that Allah would help and give blessing to His servants, who are efficient and tolerant. Moreover, it is an obligation of a Muslim to do work honestly and without being lazy in performing any task. Further, Muslims do hold a belief that Allah is aware of their intentions (Yousef, 2000). This belief will simultaneously guide the individuals to act ethically.

The work ethics in Islam constitute the expectations of one's relations with respect to his/her behavior at work. This includes his or her responsibility, cooperation, effort, dedication, creativity and social relations. Essentially, with a close association with God, one might anticipate prompting one's behavior and attitude to be consonant with the regulations and conditions of the faith (Haque, 2017). IWE advocate the importance of performing one's work to the best of his/her ability for the pleasure of God. The Qur'ān (4:29) declares, "Do not usurp your assets among yourselves wrongly except that it be trade by mutual consent".

Nasr (1984) asserts that Islam provide a climate of work within which the ethics are not separated from the economics. He argues (p. 35) that Islam bestows an ethical dimension on all kinds of work and mandates gentle behavior with them. Prophet Muhammad (PBUH) said, "Your workers are your brothers upon whom Allah has given you authority so if a Muslim has another person under his control, he/she should not overburden them with what they cannot bear and if you do so help them in their jobs" (Al Bukhari).

Given the importance of IWE and lack of attention towards IWE by the studies (Javed, Bashir, Rawwas, \& Arjoon, 2017; Khoreva \& Wechtler, 2018; Rawwas, et al., 2018), it has become certain that IWE play a key role in shaping and improving HR practices (performance appraisal, training and empowerment) in an organization. Furthermore, the role of IWE in shaping employee's performance is imperative. Therefore, the purpose of this study is to cover the existing knowledge gap by investigating the relationship of HR practices with employee's performance as well as considering the moderating role of IWE between HR practices and employee's performance.

Employees are vital asset for any organization and without the help of employees, organization cannot achieve their objectives of profitability and efficiency in the intensely competitive environment. IWE is an important concept affecting the working pattern of employees in the organizations as it involves the inculcation of Islamic principles in the employee behavior and practice. Therefore, this study places focus on some of the important HR practices, which are directly linked to the performance of employees or the organization. It also sheds light on the Islamic working patterns with the HR practices which are not tested before. For this 
study, the telecom sector of Pakistan has been taken as population as it is a platform where all the important HR practices comprising employees' training, performance appraisal and empowerment are carried out.

\section{LITERATURE REVIEW}

This section is to determine the key variables used in this study and eventually leads to the development of hypotheses set forth.

\section{Employees' Performance}

The fundamental necessity of any prosperous employer and an employee is the mutual confidence and cooperation. Both are necessary for one another to get the progress in the organization. Both are the building blocks of organization i.e., employee and the institution. Both of them work and co-operate properly all the time to get their goals (Imam, Abbasi, \& Muneer, 2013). Employees can achieve a superior performance if and only if there is cooperation between employer and employees (Riveros \& Tsai, 2011).

Iqbal, Ahmad, Haider, and Batool (2013) stated that an individual employee of an organization who works hard and strengthens the organization with his struggle, he/she not only makes the organization perfect and progressive, but indirectly makes himself strong. If he does not work hard for organization, he is not only harming the organization, but also himself. Many Human Resource Management (HRM) practices influence employees' performance, which comprise performance appraisal, Training and employee empowerment (Fong \& Li, 2010). One of the most recent researches conducted by Khoreva and Wechtler (2018) investigated the relationship between HR practices (skill enhancing, motivation, opportunity enhancing) with the job performance measures (in-role job performance, innovative job performance).

\section{Performance Appraisal and Employees' Performance}

A fair appraisal method is necessary in any organizations to maintain precious employees and increase employees' motivation at work. It makes employees to recognize their job tasks and guides them towards performance. Employee's contribution in the appraisal process, justice, equality and fairness lead to organizational commitment. Therefore, a fair appraisal helps in extracting the greatest from the workers or the employees. An unfair appraisal system can create uncertainty and frustration among the employees. Scholars generally argue that performance appraisals that are conducted accurately can enhance and improve the organizational results (Hosain, 2016). Kuvaas (2006) suggested that assessment of employee is based upon his or her performance according to the requirement of market and demand of the organization. In order to enhance the efficacy of performance appraisal system, Bizzi (2018) proposed a multilevel theory, which also addressed the supervisor's error in performance appraisal system.

The performance of an employee plays an important role in the production in terms of quality and quantity for the better results in favor of organization. Iqbal et al., (2013) indicated that to get positive and fruitful results, an employee should be helpful and doing the best. Dressler, Balieiro, Ribeiro, and dos Santos (2007) stated that an employee, male or female, 
should be correlated to organization and follow the conditions imposed by the governing authority ensuring commitment with organization. In a recent study by Clercq, Haq, and Azeem (2019) on the relationship between role ambiguity and performance appraisal, it was found that when employees are uncertain about their roles, they believe that performance appraisal was also unjust.

The intervening purpose of performance appraisal is to raise inspiration and employee's confidence. Hassan (1999) stated that performance appraisal enhanced the employee's efficiency that in turn improved the executives' performance. The performance assessments motivate employees to do more effort in order to accomplish the managerial objectives (Singh, McKeen, \& Zack, 2009).

Merit based performance assessment has an important outcome on organizational performance. Gichuhi, Abaja, and Ochieng (2013) indicated that for a sound performance, evaluation system, any organism should build up criterion for booming performance, provide performance opinion and make possible additional impartial incentive structure. It is essential that appraisers are well knowledgeable and reliable, while employees are expected to deem the performance evaluation as perfect and reasonable (Benson, 2000). Wanjala and Kimutai (2009) stated that when employees are aware of their individual roles within the structure of a group, they efficiently donate to the whole organization.

The job assessment helps employees to recognize the task expected from him/her in the accomplishment of the business objectives. Javidmehr and Ebrahimpour (2015) have indicated that performance assessment is a critical part in HRM and is a significant responsibility of managers and supervisors. In order to accomplish managerial goals, an organization needs greater understanding of the quality of work of its employees. Such understanding increases awareness of strength and weaknesses in organizational performance and behaviors. Furthermore, in an effort to develop its HR and, thus, enhance their working capacity, an organization must enhance the understanding of employee's competence. Accordingly, we suggest the following hypothesis:

H1: Perceived performance appraisal has a significant and positive impact on employees' performance.

\section{Training and the Performance of Employees}

Training is one of the imperatives of HRM as it can develop performance at individual, group and organizational levels. It is the process to increase one's ability to get achievement of organizations goals. So, training leads to understanding, leading in turn to improved performance of the employees. Elnaga and Imran (2013) mentioned training as a part of the essential HRM practice, which affects the employee's understanding, skills and ability and thus results in better performance. Studies, such as by Churchill (2017), also validate the fact that employees' training leads to the achievement of organizational objectives.

Training is one of the ways to identify the deprived needs of employees and then structure their essential capability stage so that they might do well to attain organizational goal. Singh (2012) emphasizes that organizations may spend vast amounts on the HR assets since the performance of HR eventually enhances the performance of the organization. Obeidat, 
Masadeh, and Abdallah (20014) stated that training performed a significant task in the progress of organization, refining performance as well as rising production, and ultimately putting company in the best position in the competitive environment. This implies that there is an important distinction between the organizations that guide their workers by better trainings and those that do not invest on their employees. Aguinis and Kraiger (2009) argue that training of employees generate improvement in the superiority of the work force, which in response is one of the important contributors to the nationwide economic development. Ramya (2016) contended that training enhanced the activities and performance of a human being and it was by no means an ending or constant procedure. Organizations need to realize the significance of training as an instrument to attain their planned goals. If the employees get accurate training, the accountability and surveillance responsibility of administration is lessened. The reduced need for full and continuous supervision saves time of the management and resources. Thus, we set forth the following hypothesis:

H2: Training has a significant and positive impact on employees' performance.

\section{Empowerment and Employees' Performance}

Singh, Burgess, Heap, Almatrooshi, and Farouk (2016) indicated that if someone is selected for a competent authority to perform his duties in an organization, he first of all has to obey the rules and then perform his duties being attorney to run the organization. The person who is empowered must show his performance physically and mentally so that his position and the way of handling the matters may reflect his empowerment. Psychological behavior of individual or the groups of people working for the organization plays an important role at work.

Empowerment refers to delegate the act of deciding and working according to the specific situations. Randolph (2000) contended that the main objective should be the performance. If an employees' performance is not so good, then his/her ability does not matter. Empowerment not only implies giving decision power to the employee, but also indicates intelligent and good decision-making power in order to help the persons and organisations to do work efficiently. Empowerment helps workers to be cooperative with knowledge and inner inspiration. Promoting the deserving individuals and giving them incentives helps in achieving the goal. It is all about trust and wisdom. Workers' empowerment prepares the non-managerial employees to be capable to make independent decisions without looking for suggestion of their manager.

Organizations good at communications among individuals, help to improve the workers' empowerment (Tutar, Altinoz, \& Cakiroglu, 2011). The main rationale for empowering the staff is to improve their competence so that they are able to do prompt decision and to make them accountable of their decisions. It improves employees' work life as also their morale. Meyerson and Dewettinck (2012) indicate that empowerment is a status of mentality among the staff. Continuous and the perpetual struggle of an employee, both physically as well mentally, should be considered as an asset for any organization. Demirci and Erbas (2010) found that the employees might develop both moral and materialistic matters in the organization for increasing production rate. When workers are empowered, it may lead them 
to exercise authority proficiently. Wall, Cordery, and Clegg (2002) indicated that being a competent authority in any organization, one should be careful about moral and social values for the welfare of the people, as also for increasing the production.

Empowering is a procedure by which the managers help employees to build self-governing decision and work in the organization properly and honestly (Marjani \& Alizadeh, 2014). Managers consider that empowerment provides decision-making power to the persons. Empowerment helps employees to improve their self-confidence to cope with the difficult situations at work. In a most recent work, Idris, See, and Coughlan (2018) indicated in the context of developing countries that employees' empowerment was related to job performance. Pakistan being a developing country, we set forth the following hypothesis:

H3: Empowerment has a significant and positive impact on employees' performance.

\section{Moderating Role of IWE on Performance Appraisal, Training, Empowerment And Employees' Performance}

According to Madan and Bajwa (2016), performance appraisal is to assess the performance of employees to afford superior reward and support to the employees. In case the workers recognize that the performance assessment methods applicable in the organisation are impartial and fair, it promotes the belief on the association and this finally leads to enhanced employees' performance. Woodrow (1999) suggested in the light of Islamic values three fundamental aspects about HRM in an organization, namely performance appraisal, training and empowerment. Along with that, the employees working in the light of IWE and principles could achieve their goals and objectives in better way. Rahman, Alias, Shahid, Hamid, and Alam (2013) contended that the staff must be hard working and loyal according to the requirement of job not only to do duty in this world to please the boss, but also to please Allah, being accountable to Him in the hereafter.

More recently, Javed et al. (2017) studied the relationship between IWE and adaptive performance at work. They found that indeed IWE predicted adaptive performance while the relationship was mediated by innovative work behavior. In another study, Rawwas et al. (2018) investigated the role of IWE in the relationship between organizational politics and HR related outcomes. They found that the interaction between perceived politics and IWE helped in reduction of employee's turnover intentions, increased job satisfaction and reduced negligent work behavior.

In their investigation to develop a conceptual model of Islamic working environment on employee's performance and satisfaction, Zainudin, Rashid, Murugeesan, Zainal, and Malek (2019) found that indeed Islamic work environment is related to employees' performance. In Islamic perspective, worker's performance dimension must be based on fairness and justice on the part of the employers and the sense of responsibility towards other, and accountability to Allah (taqwá) on the part of employees (Qur'ān, 49:13; 7: 85). Therefore, a true Muslim always follows Islamic principles for success and prosperity being an employer or employee in any organization.

Training bridges the gap between the existing performances and the standard or desired performance. Training can be given during different process such as peer's cooperation, 
coaching and mentoring. Training programs not merely develop workers, but also facilitate to build personnel in support of achieving competitive gains. Hence, it is necessary for the company to arrange training program for its workers to develop their capability and proficiency required at the place of work. Training also sharpens workers thoughts, creativity and ability for better and timely judgment creativity (Grant, 2006). Furthermore, it helps employees to treat the client efficiently and respond to their complaints properly (Elnaga \& Imran, 2013). Once workers consider that the training procedure is in accordance with their own beliefs and values, it would facilitate them to develop their commitment in the organizations, thus improving employee performance.

Islam focuses on attitude that facilitates keeping up of knowledge and skills. IWE is a critical variable that influences the relationship amongst employees' performance and empowerment. Imam et al. (2013) presented the situational theories that the individual qualities and convictions have impact on employees' performance. As employees' performance is associated with his skills and abilities, that is the reason an individual is assessed through selection process before beginning of work. Hence, each worker's distinct qualities collectively influence the performance of organization. Empowerment extends self-value and self-confidence of the workers, while IWE control worker performance on job through commitment and dedication. So mutually, this variable tends to develop employees' performance and loyalty. Recently, it has been found that IWE moderate the relationship between interactional justice and work engagement (Farid, Iqbal, Jawahar, Ma, \& Khan, 2019). Hence, we set forth the following hypothesis:

H4: IWE moderate the relationship between perceived performance appraisal and employees' performance such that performance improves when work ethics are high.

H5: IWE moderate the relationship between training and employees' performance such that performance improves with higher IWE.

H6: IWE moderate the relationship between employees' empowerment and employees' performance such that performance improves when the level of IWE is high.

On the basis of above formulated hypotheses, theoretical framework of the study is given below in Figure 1. 


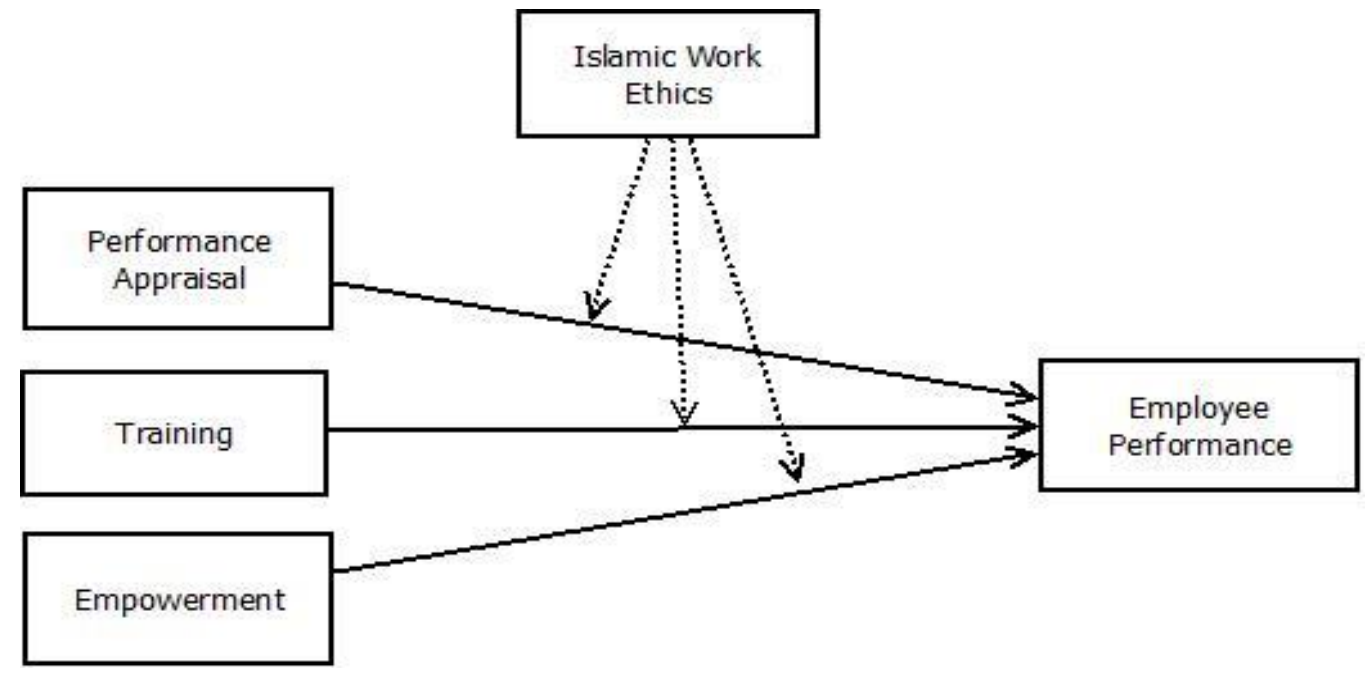

FIGURE 1. Conceptual framework

\section{RESEARCH METHODOLOGY}

This section discusses about the sample, sample size, and sampling strategy opted for this study. It also discusses the measures employed to elicit the responses from subjects.

\section{Sampling and Sample Size}

The population for the study comprises the employees of telecom sector in Pakistan. The employees of telecom sector have been chosen because this organization properly applies HR practices like performance appraisals, training and empowerment. Due to limitations of time and cost faced by the researchers, convenience sampling was used to collect data. Self-administered questionnaire was used for the purpose of data collection. Initially, five hundred questionnaires were distributed among the employees of telecom in Rawalpindi and Islamabad. The questionnaire included brief introduction of topic as well as the purpose of the study. There were total of 46 items in the questionnaire. Out of 500 distributed questionnaires, 193 questionnaires were either not returned or returned by the respondents, but were incomplete. Overall, 307 questionnaires were returned in usable form. Hence, the overall response rate was $61.4 \%$. It took almost 5 weeks to distribute and gather the responses of employees.

One hundred and seventy-two respondents were male (56\%) and the remaining 132 were females making the latter 44 percent of the sample. The responses also depicted that 166 (54\%) of employees belonged to 25-30 years of age group, 106 (34\%) were 30-35 years old, $23(8 \%)$ were $35-40$ years old and 12 (4\%) respondents were above 40 years old. Moreover, 109 (36\%) employees had income of less than Rupees 20,000, 86 (28\%) had income within the range of Rupees 20,000-30,000, 40 (13\%) had household income in the range of Rs. $30,000-40,000$ and the remaining 72 (24\%) respondents had income above 40,000. As far as education is concerned, $38(12 \%)$ employees had done matric, $52(17 \%)$ were intermediate, $79(26 \%)$ bachelors, while the remaining 138 (45\%) employees had qualification of Masters and above. 


\section{Measures}

All the study variables have been measured on a 5-point Likert scale ranging from strongly disagree $=1$ to strongly agree $=5$. Employees' performance has been measured using 6-itmes scale developed by Salanova, Agut, and Peiró (2005). Performance appraisal is measured using 9-itmes scaled developed by Snell and Dean (1992). Employees' empowerment has been measured using 11-items version by Spreitzer (1995). Training is measured using 5-itmes scales developed by Edgar and Geare (2005). IWE has been measured using a 17-items scale developed by Yousef (2000).

\section{RESULTS}

Data analysis was carried out using IBM SPSS 21. This section presents the findings of reliability and validity analysis, and regression analysis for testing the hypotheses set forth.

\section{Correlations, Reliability and Validity}

Cronbach alpha was calculated for all the scales used in this study. The rule of thumb is that alpha values above 0.7 are considered reliable. Since the alpha values for all the scales are within the acceptable range; therefore, the scale has been considered reliable to proceed for further analyses. Table 1 summarizes the alpha values of all the scales as well as correlation values of all the variables used in the study.

TABLE 1

Correlation and Reliability Analysis

\begin{tabular}{lllllll}
\hline \hline S. No. & Variable & 1 & 2 & 3 & 4 & 5 \\
\hline 1 & Performance Appraisal & $1(0.765)$ & & & & \\
2 & Training & $.403^{* *}$ & $1(0.755)$ & & & \\
3 & Empowerment & $.447^{* *}$ & $.529^{* *}$ & $1(0.817)$ & & \\
4 & IWE & $.389^{* *}$ & $.313^{* *}$ & $.554^{* *}$ & $1(0.845)$ & \\
5 & Employees' performance & $.420^{* *}$ & -.011 & $.106^{* *}$ & $.293^{* *}$ & $1(0.845)$ \\
\hline \hline
\end{tabular}

Note: Values in parenthesis indicate Cronbach alpha values.

In order to test for the validity of data, factor loadings were computed for the data. Hair, Black, Babin, Anderson, and Tatham (2006) proposed the deletion of variables that violate the limit of standardized factor loadings by 1.00 or near to it. In order to ensure the limit value of 1.00 is not exceeded, Hair et al. (2006) also suggested to set a very small error variance value of 0.005 . Table 2 shows that all the loadings were significant - no item having the loading so low to be deleted. 
TABLE 2

Construct Loadings, Average Variance Extracted (AVE) and Composite Reliability (CR)

\begin{tabular}{lll}
\hline \hline Construct & Items & Loadings \\
\hline Performance Appraisal & PA1 & .734 \\
AVE $=0.505$ & PA2 & .774 \\
CR $=0.901$ & PA3 & .694 \\
& PA4 & .762 \\
& PA5 & .666 \\
& PA6 & .665 \\
& PA7 & .673 \\
& PA8 & .715 \\
Training & PA9 & .706 \\
AVE $=0.527$ & TRA1 & .641 \\
CR $=0.847$ & TRA2 & .571 \\
& TRA3 & .567 \\
& TRA4 & .606 \\
& TRA5 & .694 \\
\hline \hline
\end{tabular}


TABLE 2 Continue

\begin{tabular}{|c|c|c|}
\hline Construct & Items & Loadings \\
\hline Empowerment & EMP1 & .678 \\
\hline $\mathrm{AVE}=0.506$ & EMP2 & .768 \\
\hline \multirow[t]{9}{*}{$\mathrm{CR}=0.918$} & EMP3 & .746 \\
\hline & EMP4 & .682 \\
\hline & EMP5 & .625 \\
\hline & EMP6 & .635 \\
\hline & EMP7 & .637 \\
\hline & EMP8 & .719 \\
\hline & EMP9 & .723 \\
\hline & EMP10 & .806 \\
\hline & EMP11 & .781 \\
\hline IWE & IWE1 & .729 \\
\hline $\mathrm{AVE}=0.575$ & IWE2 & .645 \\
\hline \multirow[t]{15}{*}{$\mathrm{CR}=0.955$} & IWE3 & .685 \\
\hline & IWE4 & .648 \\
\hline & IWE5 & .718 \\
\hline & IWE6 & .643 \\
\hline & IWE7 & .661 \\
\hline & IWE8 & .758 \\
\hline & IWE9 & .708 \\
\hline & IWE10 & .686 \\
\hline & IWE11 & .650 \\
\hline & IWE12 & .688 \\
\hline & IWE13 & .760 \\
\hline & IWE14 & .803 \\
\hline & IWE15 & .721 \\
\hline & IWE16 & .719 \\
\hline & IWE17 & .855 \\
\hline Employee performance & EP1 & .841 \\
\hline $\mathrm{AVE}=0.591$ & EP2 & .745 \\
\hline \multirow[t]{2}{*}{$\mathrm{CR}=0.852$} & EP3 & .729 \\
\hline & EP4 & .757 \\
\hline
\end{tabular}

Convergent validity has been examined using the AVE and CR. According to Fornell and Larcker (1981), the values of AVE and CR should be above 0.50 and 0.70 respectively. As seen in table 4.2, the CR values range from 0.847 to 0.955 while AVE values range from 0.505 to 0.591 . As far as discriminant validity is concerned, it can be tested when the square roots of AVE of each construct are greater than the correlations with itself and other constructs. The AVE values for performance appraisal, training, empowerment, IWE 
and employees' performance are $0.71,0.72,0.71,0.75$ and 0.76 respectively. Since all the values are greater than the correlations of these variables with other variables (see Table 1 for comparison), therefore, no discriminant validity issue found.

\section{Hypotheses Testing}

Regression analysis was performed to test the hypotheses. H1 is that perceived performance appraisal has a significant and positive impact on employee's performance. This hypothesis is supported by the analysis at $\beta=.666^{* * *}$ at significance level of $p \leq .0 .000$. The results of analyses are presented in Table 3 .

TABLE 3

Regression Analyses

\begin{tabular}{lllll}
\hline \hline & $\mathrm{B}$ & Std. Error & $t$ & Sig. \\
\hline Performance appraisal & .666 & .084 & 8.659 & .000 \\
Training & -.245 & .076 & -3.251 & .601 \\
Empowerment & .263 & .107 & .525 & .001 \\
\hline \hline
\end{tabular}

$\mathrm{H} 2$ is that training has a significant and positive impact on employees' performance. This hypothesis is not supported at $\beta=-.245$ at significance level of $p \leq .0 .05$. H3 is that empowerment had a significant and positive impact on employees' performance. According to the results, this hypothesis is supported at $\beta=.263^{* *}$ at significance level of $p \leq .0 .05$.

Moderation analysis was also performed to test the reaming hypotheses. The results of moderation analysis are presented in Table 4.

TABLE 4

Moderation Analyses

\begin{tabular}{lllll}
\hline \hline & B & Std. Error & $t$ & Sig. \\
\hline Step 1 & & & & \\
Performance appraisal & .666 & .084 & 8.659 & .000 \\
Training & -.245 & .076 & -3.251 & .001 \\
Empowerment & -.263 & .107 & -.525 & .600 \\
Step 2 & & & & \\
Performance appraisal $\times$ IWE & .117 & .042 & 2.789 & .006 \\
Training $\times$ IWE & -.018 & .030 & -.604 & .546 \\
Empowerment $\times$ IWE & .073 & .042 & 1.727 & .085 \\
\hline \hline
\end{tabular}

According to the results, $\mathrm{H} 4$ which stated that "IWE moderate the relationship between perceived performance appraisal and employee's performance such that performance will improve when IWE are high" is supported at $\beta=.117 * * *$ at significance level of $p \leq .05$. See Figure 2. 


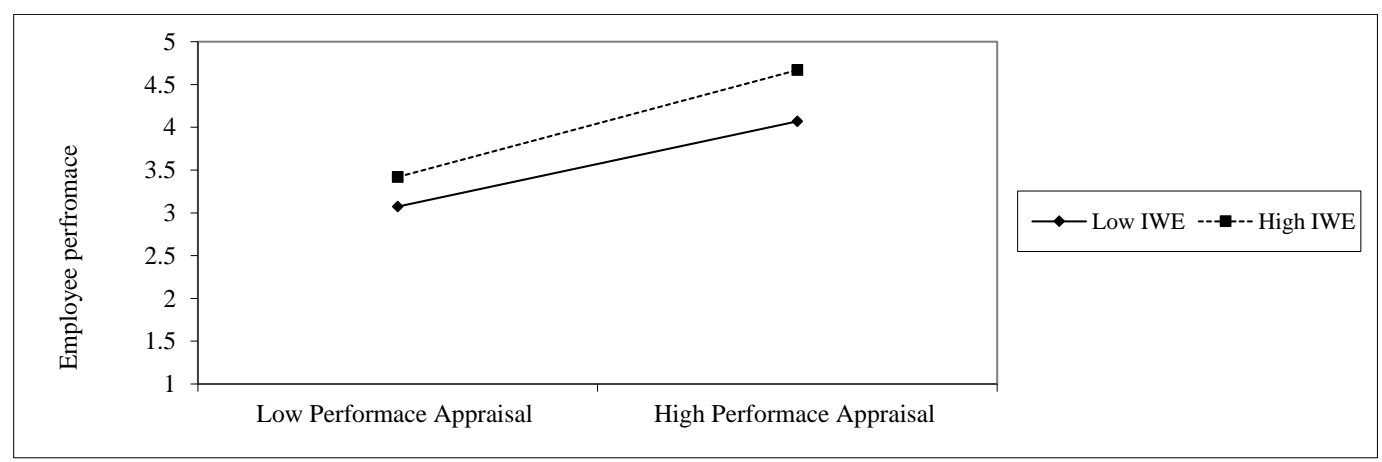

FIGURE 2. IWE moderates between performance appraisal and employee performance

H5 is that "IWE moderate the relationship between training and employee's performance such that performance improves when IWE are high". Results did not support this hypothesis ( $\beta=-.018)$. H6 theorized that "IWE moderate the relationship between employee's empowerment and performance such that employee's performance improves when IWE are high". The results supported this hypothesis at $\beta=.073 *$. See Figure 3.

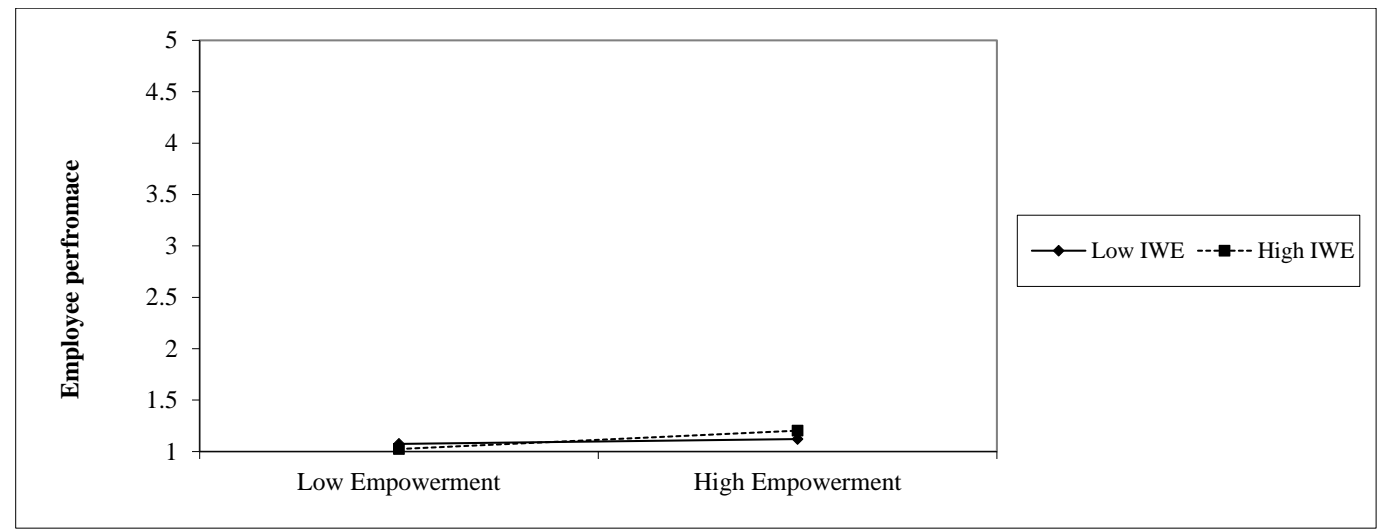

FIGURE 3. IWE moderates between empowerment and employee performance

\section{Discussion}

The basic objective of study was to find out the impact of HRM practices on employees' performance in telecom sector of Pakistan and to find out whether IWE moderate the relationship between HR practices and employees' performance. A method of moderated regression analysis developed by Cohen (2013) was used to test the proposed hypotheses. Testing of hypotheses revealed some interesting and important results. Hypothesis 1 stated that perceived performance appraisal had a significant and positive impact on employees' performance. These findings are consistent with the results of previous studies like study conducted by Kuvaas (2006) and by Singh et al. (2009).

Hypothesis 2 stated that training has a significant and positive impact on employees' performance. The relationship was not significant, while the beta value was also negative. This is not consistent with the results of previous studies. One possible explanation may be that employees' attitude/tendency towards learning is an important element that determines whether training leads to actual learning or not. Moreover, if training content is not appropriate or relevant to the needs of the trainees, then training might not lead to improvement 
in employee's performance (Baldwin \& Ford, 1988). Hypothesis 3 stated that empowerment had a significant and positive impact on employee's performance. The relationship is supported and is consistent with the results of previous studies. For example, Idris et al. (2018) stated that employees' empowerment is related to job performance in the context of developing countries. Similarly, Meyerson and Dewettinck (2012) also find that employees' empowerment leads to an increase in employees' performance.

It was posited in $\mathrm{H} 4$ that IWE moderated the relationship between perceived performance appraisal and employee's performance such that performance improves when the IWE level is high. The results are consistent with the findings of previous studies like Kuvaas (2006). Hypothesis 5 stated that IWE moderated the relationship between training and employees' performance such that the performance improves when IWE are high. These results indicate that IWE did not moderate this relationship. This is not consistent with the results of previous studies. These findings are supported by Baldwin and Ford (1988), who found that transfer of training has been a major issue in many organizations. IWE impose boundaries on individuals regarding how to interact with each other. This would prevent efficient flow of information and will lead to decrease in performance of employees.

Hypothesis 6 is that IWE moderate the relationship between employees' empowerment and their performance such that performance improves when IWE are high. Data analysis supported this hypothesis and these results are consistent with the findings of previous studies like that of Bowen and Lawler (2006).

\section{CONCLUSION}

This study endeavored to investigate the impact of HR practices (performance appraisal, training and empowerment) on the overall performance of employees. Findings of the study reveal that those managers who follow HR practices get better performance from employees. IWE plays important role in increasing the overall effectiveness of HR practices by further boosting the performance. One interesting but unusual finding was the insignificant relationship of training with employees' performance. However, it has also been observed that in those cases where trainings are either poorly designed or perceived as less valuable by the employees tend to yield no or lower performance achievement.

\section{Implications}

This study has some useful implications for researchers and practitioners. According to the findings of the study, it is imperative for managers to promote the environment of IWE at their workplace. When there is an environment based on Islamic working ethics, performance appraisal given to employees would result in higher performance of employees as compared to the environment where there is lack of IWE.

The study has another interesting implication in terms of empowerment-IWE relationship. The data analysis indicates that empowerment predicts employees' performance. But, it is also important to note that empowerment can lead to overconfidence and leniency among employees (Vancouver, Thompson, Tischner, \& Putka, 2002) and ultimately a drop in their overall performance. The analysis also showed that in the presence of IWE, empowerment 
did predict employee's performance. This result truly depicts the importance of IWE such that in those situations where empowerment fails to predict employee's performance, combining it with a culture of IWE might lead to increased performance.

For researchers, the findings of this study provide useful insights into the literature of employees' performance, performance appraisal, empowerment and IWE. Specifically, the findings regarding relationship between empowerment and IWE to predict employees' performance are important. Building upon this, researchers can identify other HR related variables and situations where role of IWE becomes imperative.

\section{Limitations and Directions for Future Research}

This study presents many opportunities for future empirical research, but had some limitations. Below, we address some methodological and theoretical issues in the current literature and discuss a number of fruitful directions for future research.

1. This research incorporates the relationship of only three variables i.e., performance appraisal, empowerment and training. Vicinity of relationship with other moderating variables like collectivism and leadership style remains largely unexplored. Future researches could focus on these unexplored variables.

2. The research caters for telecom sector in Pakistan only. Similar research may be conducted for other sectors of Pakistan like cement sector, fertilizer sector, restaurants and hospitality sectors.

3. Due to time and cost considerations, the sample size of this study was small; hence, the generalizability of this study is limited. Therefore, future studies could cater for a larger sample sizes.

\section{REFERENCES}

Aguinis, H., \& Kraiger, K. (2009). Benefits of training and development for individuals and teams, organizations, and society. Annual Review of Psychology, 60(January), 451-474. doi: https://doi.org/10.1146/annurev.psych.60.110707.163505

Baldwin, T. T., \& Ford, J. K. (1988). Transfer of training: A review and directions for future research. Personnel Psychology, 41(1), 63-105.

doi: https://doi.org/10.1111/j.1744-6570.1988.tb00632.x

Benson, J. (2000). Employee voice in union and non-union Australian workplaces. British Journal of Industrial Relations, 38(3), 453-459.

doi: https://doi.org/10.1111/1467-8543.00173

Bizzi, L. (2018). The problem of employees' network centrality and supervisors' error in performance appraisal: A multilevel theory. Human Resource Management, 57(2), 515-528. doi: https://doi.org/10.1002/hrm.21880

Bowen, D. E., \& Lawler III, E. E. (2006). The empowerment of service workers: What, why, how, and when. Managing Innovation and Change, 33, 155-169.

Churchill J., G. A. (2017). Marketing. São Paulo, Brazil: Editora Saraiva.

Cohen, J. (2013). Statistical power analysis for the behavioral sciences. New York, NY: Routledge. doi: https://doi.org/10.4324/9780203771587 
De Clercq, D., Haq, I. U., \& Azeem, M. U. (2019). Role ambiguity and perceptions of unfair performance appraisals: Mitigating roles of personal resources. Asia Pacific Journal of Human Resources, 57(2), 150-173. doi: https://doi.org/10.1111/1744-7941.12178

Demirci, M. K., \& Erbas, A. (2010). Employee empowerment and its effect on organizational performance. The International Journal of Human Resource Management, 17(8), 144199.

Dressler, W. W., Balieiro, M. C., Ribeiro, R. P., \& dos Santos, J. E. (2007). A prospective study of cultural consonance and depressive symptoms in urban Brazil. Social Science $\mathcal{E}$ Medicine, 65(10), 2058-2069. doi: https://doi.org/10.1016/j.socscimed.2007.06.020

Edgar, F., \& Geare, A. (2005). HRM practice and employee attitudes: Different measures different results. Personnel Review, 34(5), 534-549. doi: https://doi.org/10.1108/00483480510612503

Elnaga, A., \& Imran, A. (2013). The effect of training on employee performance. European Journal of Business and Management, 5(4), 137-147.

Farid, T., Iqbal, S., Jawahar, I. M., Ma, J., \& Khan, M. K. (2019). The interactive effects of justice perceptions and Islamic work ethic in predicting citizenship behaviors and work engagement. Asian Business $\mathcal{E}$ Management, 18(1), 31-50. doi: https://doi.org/10.1057/s41291-018-00049-9

Fong, Y. F., \& Li, J. (2010). Relational contracts, efficiency wages, and employment dynamics. Evanston, IL: Northwestern University, Kellogg School of Management.

Fornell, C., \& Larcker, D. F. (1981). Evaluating structural equation models with unobservable variables and measurement error. Journal of Marketing Research, 18(1), 39-50. doi: https://doi.org/10.1177/002224378101800104

Gichuhi, A. W., Abaja, P. O., \& Ochieng, I. (2013). Effect of performance appraisal on employee productivity: A case study of supermarkets in Nakuru Town, Kenya. Asian Journal of Business and Management Sciences, 2(11), 42-58.

Grant, D. (2006). Fundamentals of logistics management. New York, NY: McGraw Hill Higher Education; European Ed edition.

Haque, M. S. (2017). Legacy of the NPM model in governance: Impacts of its neoliberal principles on democracy in Asia, Africa, and Latin America. In Democratizing public governance in developing nations (pp. 15-37). New York, NY: Routledge. doi: https://doi.org/10.4324/9781315671925-2

Hair, J. F., Black, W. C., Babin, B. J., Anderson, R. E., \& Tatham, R. L. (2006). Multivariate data analysis (Vol. 6). Upper Saddle River, NJ: Pearson Prentice Hall,

Hassan, S. (1999). Impact of HRM practices on employee's performance. International Journal of Academic Research in Accounting, Finance and Management Sciences, 6(1), 15-22. doi: https://doi.org/10.6007/IJARAFMS/v6-i1/1951

Hosain, M. S. (2016). Impact of best HRM practices on retaining the best employees: A study on selected Bangladeshi firms. Asian Journal of Social Sciences and Management Studies, 3(2), 108-114. doi: https://doi.org/10.20448/journal.500/2016.3.2/500.2.108.114 
Idris, A., See, D., \& Coughlan, P. (2018). Employee empowerment and job satisfaction in urban Malaysia: Connecting the dots with context and organizational change management. Journal of Organizational Change Management, 31(3), 697-711. doi: https://doi.org/10.1108/JOCM-04-2017-0155

Iqbal, N., Ahmad, N., Haider, Z., \& Batool, Y. (2013). Impact of performance appraisal on employee's performance involving the moderating role of motivation. Arabian Journal of Business and Management Review, 3(1), 37-56. doi: https://doi.org/10.12816/0002354

Imam, A., Abbasi, A. S., \& Muneer, S. (2013). The impact of Islamic work ethic on employee performance: Testing two model of personality X and personality Y. Journal of Business and Social Science, 25(3), 611-617.

Javed, B., Bashir, S., Rawwas, M. Y., \& Arjoon, S. (2017). Islamic work ethic, innovative work behaviour, and adaptive performance: The mediating mechanism and an interacting effect. Current Issues in Tourism, 20(6), 647-663. doi: https://doi.org/10.1080/13683500.2016.1171830

Javidmehr, M., \& Ebrahimpour, M. (2015). Performance appraisal bias and errors: The influences and consequences. International Journal of Organizational Leadership, 4(3), 286-302. doi: https://doi.org/10.33844/ijol.2015.60464

Khoreva, V., \& Wechtler, H. (2018). HR practices and employee performance: The mediating role of well-being. Employee Relations, 40(2), 227-243. doi: https://doi.org/10.1108/ER-08-2017-0191

Kuvaas, B. (2006). Performance appraisal satisfaction and employee outcomes: Mediating and moderating roles of work motivation. The International Journal of Human Resource Management, 17(3), 504-522. doi: https://doi.org/10.1080/09585190500521581

Madan, D. P., \& Bajwa, J. K. (2016). Human resource management practices and their impact on the job performance of employees with special reference to banking sector. International Journal of Engineering Technology, Management and Applied Sciences, 4(4).

Meyerson, G., \& Dewettinck, B. (2012). Effect of empowerment on employees performance. Advanced Research in Economic and Management Sciences, 2(1), 40-46.

Marjani, A. B., \& Alizadeh, F. (2014). The impact of empowerment on employees performance in Standards office of Tehran. International Journal of Academic Research in Economics and Management Sciences, 3(4), 36-43.

doi: https://doi.org/10.6007/IJAREMS/v3-i4/1055

Nasr, S. H. (1984). Islamic work ethics. Hamdard Islamicus, 7(4), 25-35.

Obeidat, B. Y., Masadeh, R., \& Abdallah, A. B. (2014). The relationships among human resource management practices, organizational commitment, and knowledge management processes: A structural equation modeling approach. International Journal of Business and Management, 9(3), 9-26. doi: https://doi.org/10.5539/ijbm.v9n3p9

Ramya, S. (2016). The effect of training on employee performance. International Journal of Scientific Research and Modern Education (IJSRME), 1(1), 697-706.

Randolph, W.A. (2000). Re-thinking empowerment: why is it so hard to achieve? Organization Dynamics, 29(2), 94-107. doi: https://doi.org/10.1016/S0090-2616(00)00017-6 
Rahman, N. M. N. A., Alias, M. A., Shahid, S., Hamid, M. A., \& Alam, S. S. (2013). Relationship between Islamic Human Resources Management (IHRM) practices and trust: An empirical study. Journal of Industrial Engineering and Management, 6(4), 1105-1123. doi: https://doi.org/10.3926/jiem.794

Riveros, A. M. M., \& Tsai, T. S. T. (2011). Career commitment and organizational commitment in for-profit and non-profit sectors. International Journal of Emerging Sciences, 1(3), 324-341.

Rawwas, M. Y., Javed, B., \& Iqbal, M. N. (2018). Perception of politics and job outcomes: moderating role of Islamic work ethic. Personnel Review, 47(1), 74-94. doi: https://doi.org/10.1108/PR-03-2016-0068

Salanova, M., Agut, S., \& Peiró, J. M. (2005). Linking organizational resources and work engagement to employee performance and customer loyalty: The mediation of service climate. Journal of Applied Psychology, 90(6), 12-17. doi: https://doi.org/10.1037/0021-9010.90.6.1217

Snell, S. A., \& Dean, J. W. (1992). Integrated manufacturing and human resource management: A human capital perspective. Academy of Management Journal, 35(3), 467-504. doi: https://doi.org/10.2307/256484

Singh, S., McKeen, J., \& Zack, M. (2009). Knowledge management and organizational performance: An exploratory analysis. Journal of Knowledge Management, 13(6), 392-409. doi: https://doi.org/10.1108/13673270910997088

Singh, S. K., Burgess, T. F., Heap, J., Almatrooshi, B., \& Farouk, S. (2016). Determinants of organizational performance: A proposed framework. International Journal of Productivity and Performance Management, 65(6), 844-859. doi: https://doi.org/10.1108/IJPPM-02-2016-0038

Singh, H. (2012). Impact of Training on Employee performance. International Journal of Business Management and Scientific Research, 19(6), 87-132.

Spreitzer, G. M. (1995). Psychological empowerment in the workplace: Dimensions, measurement, and validation. Academy of management Journal, 38(5), 1442-1465. doi: https://doi.org/10.5465/256865

Tutar, H., Altinoz, M., \& Cakiroglu, D. (2011). The effects of employee empowerment on achievement motivation and the contextual performance of employees. African Journal of Business Management, 5(15), 631-638.

Yousef, D. A. (2000). The Islamic work ethic as a mediator of the relationship between locus of control, role conflict and role ambiguity-A study in an Islamic country setting. Journal of Managerial Psychology, 15(4), 283-298. doi: https://doi.org/10.1108/02683940010330966

Zahrah, S. A., \& Bidayatul, A. (2009). The relationship between Islamic religiosity, Islamic work ethics and job performance. Journal of Organizational Behavior, 35(1), 87-119.

Vancouver, J. B., Thompson, C. M., Tischner, E. C., \& Putka, D. J. (2002). Two studies examining the negative effect of self-efficacy on performance. Journal of Applied Psychology, 87(3), 506-516. doi: https://doi.org/10.1037/0021-9010.87.3.506 
Wanjala, M. W., \& Kimutai, G. (2015). Influence of performance appraisal on employee performance in commercial banks in Trans Nzoia County-Kenya. International Journal of Academic Research in Business and Social Sciences, 5(8), 332-343. doi: https://doi.org/10.6007/IJARBSS/v5-i8/1788

Woodrow, C. (1999). Revisiting images of the child in early childhood education: Reflections and considerations. Australasian Journal of Early Childhood, 24(4), 7-12. doi: https://doi.org/10.1177/183693919902400403

Wall, T. D., Cordery, J. L., \& Clegg, C. W. (2002). Empowerment, performance, and operational uncertainty: A theoretical integration. Applied Psychology, 51(1), 146-169. doi: https://doi.org/10.1111/1464-0597.00083

Zainudin, M. I., Rashid, M. S. A., Murugeesan, Y., Zainal, C., \& Malek, S. N. A. (2019). Islamic working environment, organizational commitment and employee's job satisfaction and performance in Malaysia service industry: A conceptual paper. Global Business $\mathcal{E}$ Management Research, 11(1), 436-445. 